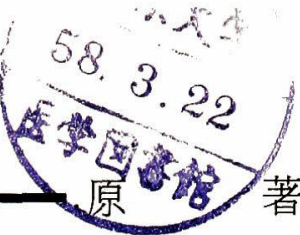

Poor R wave progressionの前胸壁マッピング心電図による診断

\author{
杏林大学医学部第二内科（指導 石川恭三教授）
}

白戸千昭

\title{
THE DIAGNOSIS OF THE ELECTROCARDIOGRAPHIC POOR R WAVE PROGRESSION : USING PRECORDIAL MAPPING ELECTROCARDIOGRAPHY
}

\author{
Chiaki ShIRATo, MD
}

The Second Department of Internal Medicine, Kyorin University School of Medicine, Tokyo

\begin{abstract}
概要 Poor R wave progression（PRWP）は陳旧性前壁中隔心筋梗塞，左室肥大，ある種の 右室肥大扣よび心疾患のない正常人において認められる心電闵所見である。本研究は前胸壁 マッピング心電図を用いて，PRWPの原因疾患を鑑別することを目的とした。標準12誘導心電 図でPRWPの基準 $\left(\mathrm{V}_{1} \mathrm{~V}_{2} \mathrm{~V}_{3}\right.$ 誘導の $\mathrm{r}$ 波が0.3mV以下)を満足する160例を対象とした。対象症 例を 4 群（前壁中隔心筋梗塞61例，左室肥大41例，肺疾患18例，正常40例）に分類した。全例 に36誘導の前胸壁マッピン゙グ心電図を記録し，枝分かれ方式でそれぞれの群を比較検討した。 各群を $V_{1} V_{2} V_{3}$ 誘導のQRS波形によつて 6 型に分類し, 各型毎に心筋梗塞と他の 3 群とを比較 した. I 型 $(\mathrm{QS} \cdot \mathrm{QS} \cdot \mathrm{QS}), \mathrm{II}$ 型 $(\mathrm{QS} \cdot \mathrm{QS} \cdot \mathrm{rS}), \mathrm{III}$ 型 $(\mathrm{rS} \cdot \mathrm{QS} \cdot \mathrm{QS}), \mathrm{IV}$ 型 $(\mathrm{QS} \cdot \mathrm{rS} \cdot \mathrm{rS})$, $\mathrm{V}$ 型 (rS・rS・QS), VI型 $(\mathrm{rS} \cdot \mathrm{rS} \cdot \mathrm{rS})$ ，一方で，初期 $\mathrm{r}$ 波の波高値によつて， $\mathrm{r}=0 \mathrm{mV}$ (4 点) から0.1mV毎にr $>0.3 \mathrm{mV}(0$ 点) なでの 5 段階の得点を付け, 得点法とした。この得点法 拉よびQSパターンの総数が，前壁中隔心筋梗塞を鑑別する有用な要素であつた。他にQRS波の 波高值, R/S比，院性T波の位置が有用な鑑別要素となつた。これらの要素を組み合わせること により，各群が下記の診断率 (sensitivity, specificity) で鑑別された。前壁中隔心筋梗塞 $\mathrm{I} \sim \mathrm{V}$ 型 $(100 \%, 100 \%), \mathrm{VI}$ 型 $(87.5 \%, 92.6 \%)$, 左室肥大 $(94.8 \%, 92.7 \%)$, 肺疾患 $(77.8 \%$, $95.1 \%)$.
\end{abstract}

\section{はじめに}

Poor R wave progression (PRWP) とは，標 準12誘導心電図の $V_{1} \cdot V_{2} \cdot V_{3}$ 誘導に括いて， R波 が減高もしくは消失した所見に対して与えられる 心電図診断名である。

PRWPは陳旧性前壁中隔心筋梗塞, 左室肥大, 慢性閉塞性肺疾患 (Cタイプ右室肥大), 左脚ブ ロック, WPW症候群, さらには正常人においても 認められる。このためPRWPが，いかなる原因疾 患に基づいて発現しているのかを鑑別すること は, 臨床心電困診断に際して重大な問題とされて いる。

〔昭和57年 7 月 5 日受稿〕
今日をでに，標準12誘導心電図や直交軸べクト ル心電図を用いて, PRWPを呈する疾患の5ち心 筋梗塞と肺気腫々の鑑別診断 ${ }^{1}$, 心筋梗塞と左室 肥大との鑑別診断2などについて検討がなされて

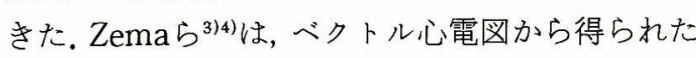
パラメーターを利用して，標準12誘導心電図によ るPRWPの診断基準を報告している.

しかし, 標準 12 誘導心電図では, 誘導数, 誘導 部位が限定されるため, 心臓前壁に由来する電気 現象のごく一部を見ているにすぎず, 診断率を高 めるには自ずと限界がある。前胸壁の誘導数を増 加させ, 誘導部位を変化させることによつて, そ れぞれの原因疾患を鑑別し得る特徵的なパラメー ターが抽出されるかどうかの検討は未だ報告され 
ていないそこで本研究では，PRWPを示した症 例に，前胸壁マッピング心電図（36誘導）を記録 し，それにより得ら机た情報を基に，PRWPを示 す原因疾患の鑑別を試みた。

\section{対象および方法}

標準12誘導心電図の $V_{1} V_{2} V_{3}$ 誘導が全て，QS patternであるか，もしくは $\mathrm{r}$ 波高が0.3mVを越 えないrS patternである心電図所見を，PRWPと 定義した。

本研究に括ける対象は，上記のPRWPの基準を 満足する症例のらち，左脚ブロック，WPW症候 群，心室内伝導障害を除外した160例である。対象 例臨木所見により下記の 4 群に分類した。

（1）心筋梗塞群 (61例；男38例, 女 23 例；年令： 平均67.5才,41才一92才)：臨床経過より急性心 筋梗塞が明らかで, ${ }^{201} \mathrm{~T}$ 心筋シンチグラムにおい て前壁もしくは中隔部に欠損像が認められた症例 で，発症後14日以上経過している症例を陳旧性前 壁中隔心筋梗塞群とした。

（2）左室肥大群(40例；男18例, 女 22 例；年令： 平均 48.8 才, $28 \sim 88$ 才)：升膜症，心筋症，高血 在症例で，心ェコ一図に扒いて心室中隔打よび左 室後壁の壁厚が $10 \mathrm{~mm}$ 越え，しかも ${ }^{201} \mathrm{~T} l$ 心筋ン ンチグラムで久損像の認められない症例を左室肥 大群とした。

（3）肺疾患群（18例；男11例，女 7 例；年令： 平均 58.3 才, 18－72才）：臨床診断で, 慢性閉塞 性肺疾患之診断され，上記の前壁中隔心矨梗塞お よび左室肥大の基準を満足しない症例を肺疾患 （Cタイプ右室肥大）群とした。

（4）正常群 (40例；男23例，女17例；年令：平 均32.4才, 20〜56才)：臨床診断で, 心循環系に 影響を与えるよらな基礎疾患を有しない症例を正 常群とした。

対象症例全例に, 6 チャンネルのミンゴグラフ 800 (フクダ電子社製）を使用し，紙送り速度25 $\mathrm{mm} / \mathrm{sec}, 6$ 回切り替えによつて，36誘尊よりなる 前胸壁マッピング心電図を記録した。36誘導点は, 綐例が標準 12 誘導心電図の胸部誘導上同様に，胸 骨右縁上り中腋窩線までの 6 行 $(\mathrm{a} \sim \mathrm{f})$ ，横列が第
1 肋間より胸骨剣状突起末で肋間ごとに 6 列（1 ～6）に配列した（図 1)。

記録された前胸壁マッビング心電図所見を用い て，各疾患群ごとに比較検討を行なつた。

\section{［A］陳旧性前壁中隔心筋梗塞と他の 3 群と の鑑別}

対象症例全例を，標準12誘導心電図の $V_{1} V_{2} V_{3}$ 誘導のQRS波形によつて，次の 6 型に分類した。 例えば， $V_{1}$ 誘導が $Q S$ pattern, $V_{2}$ 誘導がrS pattern, $V_{3}$ 誘導が $\mathrm{rS}$ patternの場合には ( $\mathrm{QS}, \mathrm{rS}, \mathrm{rS}$ ) で示す.

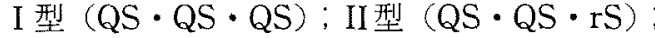

III型 $(\mathrm{rS} \cdot \mathrm{QS} \cdot \mathrm{QS})$; IV型 (QS $\cdot \mathrm{rS} \cdot \mathrm{rS})$;

$\mathrm{V}$ 型 $(\mathrm{rS} \cdot \mathrm{rS} \cdot \mathrm{QS}) ; \mathrm{VI}$ 型 $(\mathrm{rS} \cdot \mathrm{rS} \cdot \mathrm{rS})$.

この型別に，陳旧性前壁中隔心筋梗塞群之非梗 塞群（左室肥大群・肺疾患群・正常群）との間で 以下の検討を行なつた。

（イ）36誘導中に認め5れる異常 $\mathrm{Q}$ 波の数 (nQ).

ここで異常 $\mathrm{Q}$ 波は，Q幅が0.04秒以上で，Q波 高值が r 波高值の1/4を越えるものと定義したな 扣QS patternは異常Q波に含まれるものとした。

(口) 得点法

前胸壁マッピング心電図の各誘導に㧊ける $\mathrm{r}$ 波 の減衰度を定量化する目的で， $\mathrm{r}$ 波高值によつて 5 段階に分類し，以下の得点を付与した。

異常 $\mathrm{Q}$ 波求よびQS pattern：4点

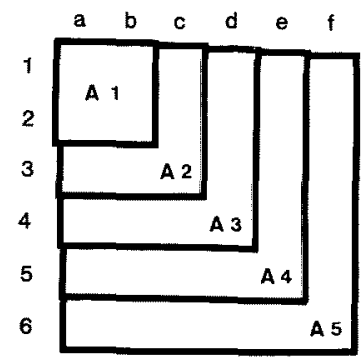

図 1。体表面マッピング心電図の誘導名㧍上び設定領 域.

$\mathrm{a}$ 一f， 1 - 6 㹥体表面マッピング心電図の縋軸拈上 び横軸の誘導名，例えば(b-4)誘導， $A_{1} \sim A_{5}$ 快設定さ 机大領域名。例兄代， $A_{2}$ 領域は $(\mathrm{a}, \mathrm{b}, \mathrm{c}) \times(1,2$ ， 3) 誘導の計 9 誘導 
r波高值が0.1mV以下： 3 点

$\mathrm{r}$ 波高値が0. $2 \mathrm{mV}$ 以下： 2 点

$\mathrm{r}$ 波高値が $0.3 \mathrm{mV}$ 以下：1点

$\mathrm{r}$ 波高値が0.3mVを越える：0 点

この得点法に従つて, 各症例の得点表を作成した。

次いで，得点表を右上方から左下方へ向かつて 広がる 5 領域に区分した（図 1)。

$A_{1}$ 領域: $(a \sim b) \times(1 \sim 2): 4$ 誘導 $A_{2}$ 領域: $(a \sim c) \times(1-3) ; 9$ 誘導

$\mathrm{A}_{3}$ 領域: $(a \sim d) \times(1 \sim 4) ; 16$ 誘導 $A_{4}$ 領域: $(a \sim e) \times(1 \sim 5) ; 25$ 誘導 $A_{5}$ 領域 : $(a \sim f) \times(1 \sim 6) ; 36$ 誘導

各症例ごとに各領域の得点合計を求め，陳旧性 前壁中隔心筋梗塞群と非梗塞群との間で比較検討 を行なつた。

（八）非梗塞群（左室肥大群・肺疾患群・正常群） 間で, 36誘導中の異常 Q波の数(イ), 得点法 $(\square)$, を用いて比較した。

\section{[B] 左室肥大群と肺疾患群ならびに正常群 との鑑別}

陳旧性前壁中隔心筋梗塞群を除外し，左室肥大 群と非左室肥大群 (肺疾患群, 正常群) との間で, 前胸壁マッピング心電図の各棘波を用いて比較検 討した。

\section{[C] 肺疾患群と正常群との鑑別}

慢性閉塞性肺疾患群（Cタイプ右室肥大群）と 正常群との間で, 前胸壁マッピング心電図の各棘 波を用いて比較検討した。

\section{[D] 診断基準の作成}

各疾患群ごとに得られた鑑別基準を用いて枝分 かれ方式によるPRWPの診断基準を作成した。

\section{結 果}

\section{[A] 陳旧性前壁中隔心筋梗塞と他の 3 群の} 鑑別

標準 12 誘導心電図の 6 型分類に基づいた陳旧性 前壁中隔心筋梗塞群 (AMI群) の出現頻度を（表 1)に示した。

対象症例中, I 型（QS • QS • QS） は17例, III 型 $(\mathrm{rS} \cdot \mathrm{QS} \cdot \mathrm{QS})$ は11例が認められ，ともに全例 がAMI群であつた．II型（QS・QS・rS）は15例
で，らちAMI群は13例 $(86.7 \%)$ ，残る 2 例は左室 肥大群（特発性肥大性心筋症 1 例，動脈硬化症 1 例）であつた，IV型（QS・rS・rS）は19例存在し たが，AMI群は7例 $(36.8 \%)$ に過ぎず，残りは 左室肥大群 5 例（弁膜症 2 例，動脈硬化症 3 例)， 肺疾患群 1 例, 正常群 6 例之, 全ての疾患群に散 在していた。 $\mathrm{V}$ 型 (rS・rS・QS) は 8 例のみで, 内訳はAMI群 5 例 (62.5\%), 左室肥大群 3 例（特 発性肥大性心筋症 1 例, 動脈硬化症 2 例) であつ た。 VI型 $(\mathrm{rS} \cdot \mathrm{rS} \cdot \mathrm{rS})$ は最も数が多く90例存在 したが，AMI群は 8 例 (8.9\%) と少なく，左室肥 大群31例, 肺疾患群 17 例, 正常群 34 例々心筋梗塞 を伴わない群が多かつた。

次に，この標準12誘導心電図による6 型それぞ れについて，体表面マッピング心電図を用い，

AMI群と非MI群（左室肥大群・肺疾患群・正常群） との間で，さらに詳しい比較検討を行なつた（表 2). その際，I型 (QS・QS・QS)扔上びIII型( $\mathrm{rS} \cdot$ $\mathrm{QS}$-QS) は全例AMI群であつたため検討から除外 した.

II 型（QS・QS・rS）：（イ）異常 $\mathrm{Q}$ 波の数を示 すnQは, AMI群が15.8であるのに対し，非MI群で は10.0で，AMI群に明らかに多く認められた。 (口) $\mathrm{A}_{1}$ から $\mathrm{A}_{5}$ 領域までの得点の推移を見ると， $A_{1}$ 領域ではAMI群は16点 ( 1 誘導平均得点 4.0 点) で，これは全例が $\mathrm{A}_{1}$ 領域上の 4 誘導全てがQS patternであつたことを示している。一方非MI群

表 1、標準 12 誘導心電図の 6 型分類にもとつく，陳旧 性前壁中隔心施梗塞，左室肥大，肺疾患，正常人の出 現頻度.

症例数（それぞれの型に占める，疾㶳の\%)

\begin{tabular}{|c|c|c|c|c|c|c|c|c|}
\hline 型 & $v_{1}$ & $v_{2}$ & $v_{3}$ & 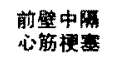 & 左室肥大 & 肺实睢 & 正常 & 尌 \\
\hline I & (QS & QS & QS) & $17(100.0)$ & $0(0)$ & $0(0)$ & $0(0)$ & 17 \\
\hline II & (QS & QS & rs) & $13(86.7)$ & $2(13.3)$ & $0(0)$ & $0(0)$ & 15 \\
\hline III & (rs & QS & QS) & $11(100.0)$ & $0(0)$ & $0(0)$ & $0(0)$ & 11 \\
\hline N & CQS & rs & $r S)$ & $7(36.8)$ & $5(26.3)$ & $1(5.3)$ & $6(31.6)$ & 19 \\
\hline v & (rs & rs & QS) & $5(62.5)$ & $3(37.5)$ & $0(0)$ & $0(0)$ & 8 \\
\hline \multirow[t]{2}{*}{ VI } & (rs & rs & $r s)$ & $B(\quad 8.9)$ & $31(34.4)$ & $17(18.9)$ & $34(37.8)$ & 90 \\
\hline & & 的 & & 61 & 41 & 18 & 40 & 160 \\
\hline
\end{tabular}


表 2。標準12誘尊心電図 6 型分類にもとつく，前胸壁マッピング心電図の異常Q波の 数圠よび設定領域ごとの得点。

心肪梗塞には陳旧性前壁中隔心筋梗塞が，非梗塞には左窒肥大・肺矣患扣上び正常 例が含まれる。

\begin{tabular}{|c|c|c|c|c|c|c|c|c|c|c|}
\hline 型 & $v_{1}$ & $v_{2}$ & $v_{3}$ & 症例数 & A | 領域 & A 2 領域 & A 3 項域 & A 4 領域 & A 5 領域 & $\begin{array}{l}\text { 異常Q } \\
\text { 波の数 }\end{array}$ \\
\hline \multirow{2}{*}{\multicolumn{2}{|c|}{ I (QS }} & QS & QS) & 心䇥掼 & $15.6 \pm 0.9$ & $35.3 \pm 1.4$ & $60.2 \pm 4.2$ & $83.5 \pm 9.8$ & $97.2 \pm 13.2$ & $21.8 \pm 5.1$ \\
\hline & & & & 翡梗害(0) & - & - & - & - & - & - \\
\hline \multirow{2}{*}{\multicolumn{2}{|c|}{ II $(Q S$}} & QS & $r S)$ & 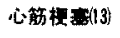 & $16.0 \pm 0.0$ & $35.7 \pm 0.5$ & $59.5 \pm 4.3$ & $75.8+10.4$ & $86.6 \pm 12.9$ & $15.8 \pm 3.4$ \\
\hline & & & & 非梗寒(2) & 15.0 & 31.5 & 48.5 & 59.0 & 66.5 & 10.0 \\
\hline \multirow[t]{2}{*}{ III } & (rS & QS & QS) & 心第掖害(1) & $13.7 \pm 2.4$ & $31.9 \pm 4.3$ & $56.6 \pm 5.4$ & $80.5 \pm 12.3$ & $95.3 \pm 14.1$ & $18.0 \pm 4.4$ \\
\hline & & & & 非㛐㥶(0) & - & - & - & - & - & -- \\
\hline \multirow[t]{2}{*}{ N } & (QS & rs & rS) & 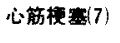 & $16.0 \pm 0.0$ & $34.1 \pm 1.7$ & $54.7 \pm 4.7$ & $71.1 \pm 12.6$ & $82.3+14.9$ & $13.3 \pm 3.8$ \\
\hline & & & & 非提寒(12) & $13.8 \pm 1.7$ & $28.0 \pm 3.8$ & $41.8 \pm 6.3$ & $50.7 \pm 8.7$ & $57.9 \pm 8.8$ & $5.1 \pm 1.7$ \\
\hline \multirow[t]{2}{*}{ v } & (rs & rs & QS) & 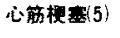 & $15.8 \pm 0.4$ & $34.6 \pm 1.1$ & $59.4 \pm 2.7$ & $85.8 \pm 5.9$ & $104.4 \pm 10.0$ & $22.0 \pm 2.5$ \\
\hline & & & & 非揁寗(3) & 13.0 & 29.3 & 45.7 & 57.7 & 70.0 & 9.7 \\
\hline \multirow[t]{2}{*}{ vi } & Crs & rs & rs) & 心筋枚害 8 ） & $15.4 \pm 1.1$ & $32.5 \pm 2.7$ & $50.4 \pm 5.8$ & $59.8 \pm 7.7$ & $66.1 \pm 10$ & $10.1 \pm 5.3$ \\
\hline & & & & 非 梗 塞(82) & $12.4 \pm 1.9$ & $25.6 \pm 4.5$ & $38.6 \pm 8.0$ & $47.3 \pm 10.6$ & $54.1 \pm 13.1$ & $2.0 \pm 2.9$ \\
\hline
\end{tabular}

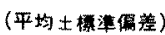

に执いては，r波の存在する誘導が混在している ため， 1 誘導平均得点は3.7点と低い。このAMI群 と非MI群の得点差は， $A_{1} か ら A_{5}$ へと領域を広げ るに従つて增加し，異常 $\mathrm{Q}$ 波を含むr波の減高が， MI群に扣いてょり著しく広範囲に及んでいるこ とを示している。

IV型（QS・rS・rS）：（イ）nQはAMI群13.7, 非MI群 5.1 と明らか化AMI群が高かつた（P< 0.01）（口）得点法で見ると，AMI群はII型と同 様, $A_{1}$ 領域の 4 誘導が全てQS patternであり, 領 域の広がりについて非MI群との得点差は増加し た。 をた，AMI群の得点は，全領域を通じて明ら かに非MI群より高かつた（各領域とも $\mathrm{P}<0.01$ ）。

$\mathrm{V}$ 型（rS・rS・QS）：（イ）nQk拈いては， AMI群 22.0, 非MI群5.1と, 全ての型のうちで最 ๖ 2 群間の異常 $\mathrm{Q}$ 波の数の差が大きかつた。（口） 一方，得点法で見ると，II・IV型と異なり，AMI 群に括いても $A_{1}$ 領域でrS patternを示す症例が存 在した。しかし，非MI群と比較すれば，AMI群の
万が得点が高く，しかも領域が広がるにつれて， 他型上りも大きく得点差の広がる傾向を示した。 このことは，V型の $\mathrm{r}$ 波の減高は右上方よりも左 上方に強いことを示している。

$\mathrm{VI}$ 型 $(\mathrm{rS} \cdot \mathrm{rS} \cdot \mathrm{rS})$ ：（イ）nQを見ると，AMI 群で10.1と，他の 5 型のそれに比して最も小さい が, 非MI群においては2.0とさらに小さく，明らか にAMI群が高かつた $(\mathrm{P}<0.01)$. (口) 得点法で は, AMI群, 非MI群ともに, $\mathrm{A}_{1}$ 領域上にrS pattern を示す症例が認められたが，得点はAMI群が明ら が高かつた $(\mathrm{P}<0.01)$ 。市た， $\mathrm{A}_{3}$ 領域までは， $\mathrm{II} \cdot \mathrm{IV}$ 型と同様, AMI群と非MI群の得点差が広が つたが， $A_{4} \cdot A_{5}$ 領域においては，得点差は変化し なかつた（全ての領域で $\mathrm{P}<0.01 ） 。$

(一) 左室肥大群・肺疾患群・正常群の非梗塞 3 群間で異常 $\mathrm{Q}$ 波の数括よび得点法の比較検討を行 なつた。異常 $\mathrm{Q}$ 波の数では, 左室肥大群は3.8土3.7 誘導(平均土標準偏差; 䇿囲： $0 \sim 16$ 誘導)，肺 疾患群は $3.0 \pm 2.8$ 誘導(範囲：0 0 ～誘導)，正 
常群は2.1土2.0誘導（範囲： $0 \sim 9$ 誘導）と， 左室肥大群が正常群上りも多い $(\mathrm{P}<0.05)$ が, 肺 疾患群と左室肥大群・正常群之の間では有意な差 が見られなかつた（P>0.05）。得点法を見ると， $\mathrm{A}_{1}$ 領域では左室肥大群 $13.0 \pm 1.9$ 点 (平均 3.3 点), 肺疾患群 $12.8 \pm 2.1$ 点(平均 3.2 点), 正常群 $12.4 \pm$ 2.0 点（平均 3.1 点）であり，3群間には特異な差 が認められず（P>0.05），3群ともに異常 $\mathrm{Q}$ 波が ほとんど含まれていなかつた， $A_{2} \sim A_{5}$ 領域の得点 に招いても，非梗塞 3 群間に有意な得点差は認め られなかつた $(\mathrm{P}>0.05)$. 代表として正常群の領 域別の得点を見ると， $A_{2} 25.0 \pm 4.7$ 点（平均2.8 点), $\mathrm{A}_{3} 39.7 \pm 8.0$ 点 (平均 2.5 点), $\mathrm{A}_{4} 48.9 \pm 10.9$ 点 (平均2.0点), $\mathrm{A}_{5} 55.6 \pm 12.9$ 点 (平均1.5点)

と, 平均した得点の低下傾向が認められた。 しか し，実際の症例毎にグラフ化して見ると，左室肥 大群が $\mathrm{A}_{3}$ 領域を過ぎた後, 増加率が急速に低下寸 る症例が多いのに対し，正常群および肺疾患群は $\mathrm{A}_{3}$ 領域を過ぎても，正均した増加傾向を示す症例 が多からた。

[B] 左室肥大群と肺疾患群・正常群との鑑別 36誘導のマッピング心電図に扔ける，陰性 $\mathrm{P}$ 波 を示す誘導数，P波陰性部分の幅（秒）と深さ $(\mathrm{mm})$ の積の合計，各誘導ごとのQ $\cdot \mathrm{R} \cdot \mathrm{S}$ 棘波高 およびR波から $\mathrm{S}$ 波（Q波）までの振幅，陰性 $\mathrm{T}$ 波を示す誘導部位について，左室肥大群と非左室 肥大群 (肺疾患群・正常群) との間で比較検討し た. 陰性 P波を示す誘導数は左室肥大群 $9.4 \pm$ 5.2 (平均士標準偏差), 非左室肥大群 $9.1 \pm 4.8$ 上 両者間に有意な差を認めなかつた。P波陰性部分 の幅 (秒) と深さ $(\mathrm{mm})$ の積の合計は左室肥大群 $(-0.19 \pm 0.12)$ の方が非左室肥大群 $(-0.15 \pm$ $0.11) よ り$ 明らかに低値を示した $(\mathrm{p}<0.05) 、 Q$ 波・R波・S波の各棘波高就よびR波から $\mathrm{S}$ 波（Q 波)までの振幅をそれぞれの誘導ごとに左室肥大 群と非左室肥大群とで比較した，Q波高で有意な 差を認めた誘導はなく，R波高に扣いては(e-5) 誘導：(左室肥大群 $2.43 \pm 1.28 \mathrm{mV}$, 非左室肥大群 $1.41 \pm 0.48 \mathrm{mV} ; \mathrm{p}<0.001),(\mathrm{e}-6):(2.62 \pm$

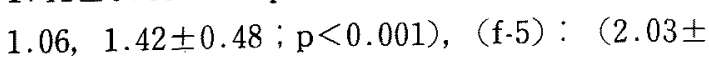

$0.98,1.28 \pm 0.44 ; \mathrm{p}<0.001),(\mathrm{f}-6):(2.11 \pm$ $1.18,1.18 \pm 0.36 ; \mathrm{p}<0.001)$ の 4 誘導において 明らか差が認められた。 S 波高では，(b-5） $(2.38 \pm 1.05,1.72 \pm 0.74 ; \mathrm{p}<0.001),(\mathrm{b}-6)$ : $(2.05 \pm 1.12,1.22 \pm 0.54: \mathrm{p}<0.005)$ 2 誘導で 有意な差が認められた。振幅では，(a-4）: $(1.52 \pm 0.67,1.16 \pm 0.49 ; \mathrm{p}<0.05)$ ，(b-4): $(2.40 \pm 1.08,1.82 \pm 0.74: p<0.05), \quad(b-5):$ $(2.52 \pm 1.15,1.80 \pm 0.77 ; \mathrm{p}<0.001),(\mathrm{b}-6)$ : $(2.10 \pm 1.24,1.26 \pm 0.60 ; \mathrm{p}<0.005),(\mathrm{e}-5)$ : $(2.69 \pm 1.35,1.53 \pm 0.62 ; \mathrm{p}<0.001), \quad(\mathrm{e}-6):$ $(2.74 \pm 1.16, \quad 1.54 \pm 0.58 ; p<0.001), \quad(f-5)$ : $(2.13 \pm 1.08,1.31 \pm 0.47 ; \mathrm{p}<0.001),(\mathrm{f}-6)$ : $(2.13 \pm 1.24,1.25 \pm 0.38 ; \mathrm{p}<0.001), 36$ 誘導中

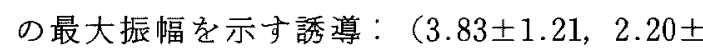
$0.65 ; \mathrm{p}<0.001)$ に扔いて両者間に有意差が認め られた。陰性 $\mathrm{T}$ 波を示す誘導部位を見ると，左室 肥大群で $\mathrm{f}$ 誘導に陰性 $\mathrm{T}$ 波を認める症例は，41例 中29例 $(70.7 \%)$ であり, 非左室肥大群では58例 中 3 例 (5.2\%)であつた。これらの有効な指標を 組み合わせ，左室肥大の診断率を最も高める指標 を抽出した。

\section{[C] 肺疾患群と正常群との鑑別}

36 誘尊のマッピング心電図に括ける，P波陽性 部分の波高値の合計，各誘導ごとのQ・R・S波高 特よびR/S比について肺疾患群と正常群との間で 比較検討した。 $\mathrm{P}$ 波陽性部分の波高值の合計は， 肺疾患群 $0.93 \pm 0.87 \mathrm{mV}$, 正常群 $1.06 \pm 0.92 \mathrm{mV}$ 有意な差を認めなかつた $(\mathrm{p}>0.05)$ ，Q波扣よび R波に执いて有意な差を喼める誘導は存在しなか つた. S波では(d-6)誘導：(肺疾患群 $0.93 \pm 0.68$,

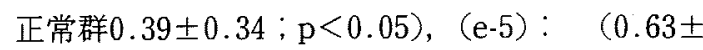
$0.41,0.17 \pm 0.13 ; \mathrm{p}<0.01), \quad(\mathrm{e}-6): \quad(0.48 \pm$ $0.32, \quad 0.10 \pm 0.07 ; \mathrm{p}<0.01),(\mathrm{f}-5): \quad(0.23 \pm$ $0.14, \quad 0.03 \pm 0.06 ; \mathrm{p}<0.01) の 4$ 誘導が, $R / S$ 比

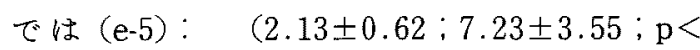
$0.01),(\mathrm{e}-6): \quad(2.26 \pm 0.46 ; 11.54 \pm 4.96$; $\mathrm{p}<0.01),(\mathrm{f}-5): \quad(3.95 \pm 1.66 ; 10.38 \pm 4.72$; $\mathrm{p}<0.02) の 3$ 誘導が有意な差を認めた。これらの 有効な指標を組み合わ姉，肺疾患の診断率を最も 
高める指標を抽出した。

\section{[D] 診断基準の作成}

各疾患群ごとに得られた鑑別基準を用いて，枝 分かれ方式によるPRWPの診断基準を作成した。

（1）陳旧性前壁中隔心筋梗塞の診断基準(図 2) 前胸壁マッピング心電図に括ける(イ） $\mathrm{nQ}$, (口) 各領域の得点数, を組み合わせることによつ て, AMI群と非MI群を最もよく鑑別する基準を, 前述の 6 型についてそれぞれの型ごとに作成し， その診断率を調べた。

I 型 $(\mathrm{QS} \cdot \mathrm{QS} ・ \mathrm{QS})$ およびIII型 $(\mathrm{rS} ・ \mathrm{QS} ・ \mathrm{QS})$ : 全例方AMI群であつた。

II 型（QS・QS・rS）は図 2-a に示すごとく $\mathrm{nQ}$ が14以上であるか， $A_{3}$ 領域における得点が57点以 上である場合には, sensitivity $100 \%$, specificity 100\%でAMIが診断された。

$\mathrm{IV}$ 型 $(\mathrm{QS} \cdot \mathrm{rS} \cdot \mathrm{rS})$ は図 2 - b で明らかなごと く, nQが 9 以上(であるか， $\mathrm{A}_{3}$ 領域に括ける得点 が50点以上）である場合には， sensitivity 100\%， specificity $100 \%$ でAMIが診断された。

$\mathrm{V}$ 型 $(\mathrm{rS} \cdot \mathrm{rS} ・ \mathrm{QS})$ は，図 2-cから明らかな ように，nQが17以上(であるか， $\mathrm{A}_{4}$ 領域に拈ける 得点が71点以上）である場合には, sensitivity 100\%, specificity 100\%でAMIが診断された。

VI型 $(\mathrm{rS} \cdot \mathrm{rS} \cdot \mathrm{rS})$ は, 図 2-dで明示されてい るごとく, nQが 6 以上で, かつ $\mathrm{A}_{2}$ 領域の得点が31 点以上の場合には, sensitivity $87.5 \%$, specificity $92.6 \%$ でAMIが診断された。

\section{（2）左室肥大の診断基準作成}

36誘導中で最大の振幅を示す誘導の波高值が $3.2 \mathrm{mV}$ 以上であるか，陰性T波を有する誘導が $\mathrm{f}$ 誘導に認められる場合には，左室肥大はsensitivity $94.8 \%$, specificity $92.7 \%$ で診断できた。

（3）慢性閉塞性肺疾患の診断基準

(e-6) 誘導のR/S比が5.0以下で, から S 波高值 が0.5mV以上である場合には, sensitivity $77.8 \%$, specificity $95.1 \%$ で慢性閉塞性肺疾患が 診断できた。

ここで, 陳旧性前壁中隔心筋梗塞 (図 3), 左室 肥大（図 4), 正常 (図 5) の症例を呈示した。
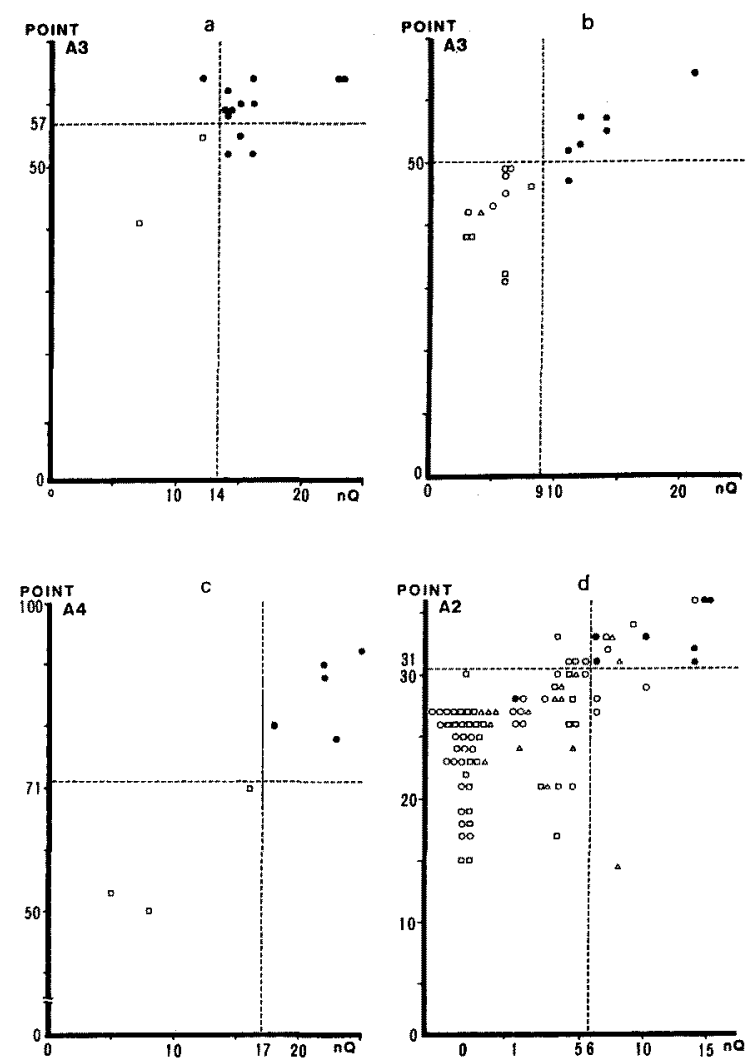

㘠 2、前胸壁マッピング心電浢による陳旧珄前壁中隔 心筋梗塞の診断基篗.

$a ：$ II 型 $(\mathrm{QS} \cdot \mathrm{QS} \cdot \mathrm{rS}), \mathrm{b}: \mathrm{IV}$ 型 $(\mathrm{QS} \cdot \mathrm{rS} \cdot \mathrm{rS})$, $\mathrm{c}: \mathrm{V}$ 型 $(\mathrm{rS} \cdot \mathrm{rS} \cdot \mathrm{QS}), \mathrm{d}$ ：VI型 $(\mathrm{rS} \cdot \mathrm{rS} \cdot \mathrm{rS}) \mathrm{k}$ 関して，異常 $\mathrm{Q}$ 波の数之特定領域の得点上Kよつて得 られた疾患分布因。粉軸には，II・IV型が $\mathrm{A}_{3}$ 領域，V 型が $\mathrm{A}_{4}$ 領域、VI型では $\mathrm{A}_{2}$ 領域の得点数を，横軸には異 常 $\mathrm{Q}$ 波の数を示寸。陳旧性前壁中隔心筋梗塞,

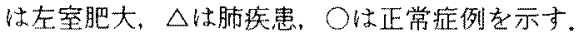

\section{考案}

PRWPは標準12誘導心電図の $V_{1} V_{2} V_{3}$ 誘導に括 いてR波が減高もしくは消失した所見に対して与 兄らる䛦断名であるが，その基準については研 究者間で必ずしも一致を見ていない. $V_{1} V_{2} V_{3}$ 誘 導に招いてR/S比が段階的に減少するものを言う 場合5) と，初期 $\mathrm{R}$ 波が絶対的に減少するものを言 う場合 ${ }^{6 / 7)}$ とがある。

このPRWPが古くから問題にされ，現在もな お，新しい問題としてありつつけているのは，こ 


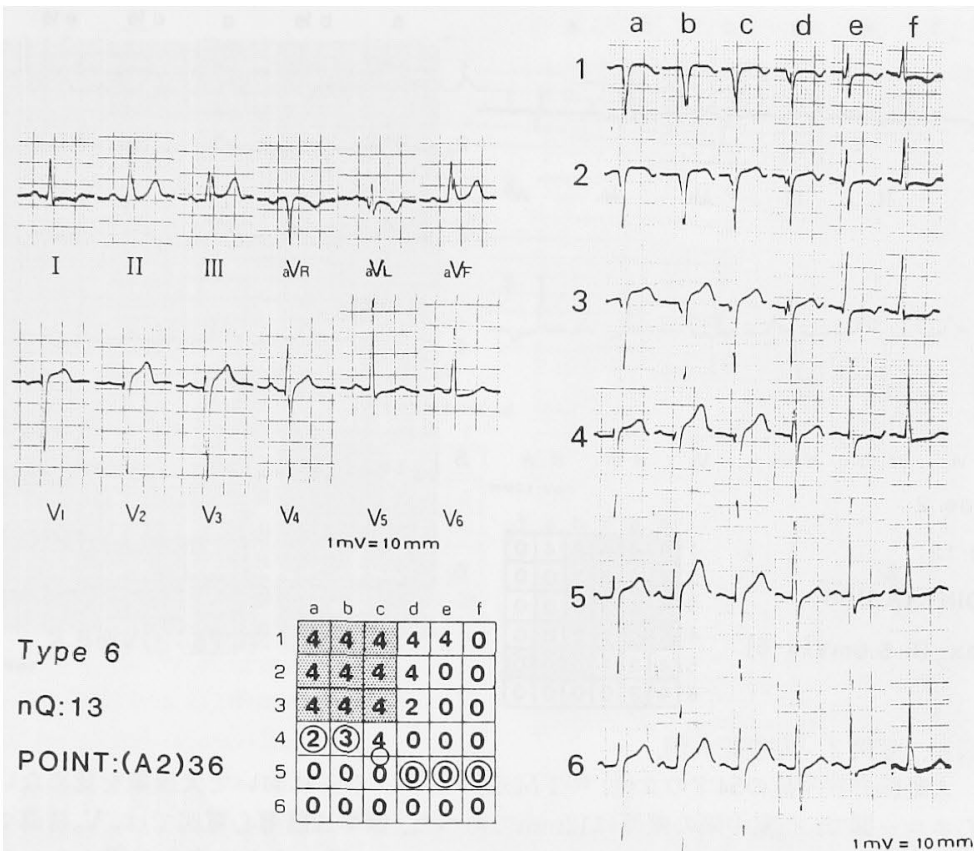

図 3. 症例 1 陳旧性前壁中隔心筋梗塞例

急性心筋梗塞発症後, 30 日を経過した 54 才の男性. ${ }^{201} \mathrm{~T} l$ 心筋シンチグラムにて, 前 壁および心室中隔部に欠損像を認めた。標準12誘導心電図では，VI型 $(\mathrm{rS} ・ \mathrm{rS} ・ \mathrm{rS})$ のPRWPで， $V_{1} \sim V_{4}$ 誘導にinitial notchが認められ，心筋梗塞の存在が疑われた，前 胸壁マッピング心電図では $V_{1} V_{2} V_{3}$ 誘導より 1 助間上およびその上方の誘導は全て $Q S$ patternを呈し，nQは13であつた，VI型であるため $\mathrm{A}_{2}$ 領域の得点を見ると36点であり， 診断基準により陳旧性前壁中隔心筋梗塞と診断された。

の所見を示す基礎疾患には臨床上重大な疾患が多 く含まれているからである。

また，現在までに報告されたPRWPの臨床的評 価に関しても，各研究者間にかなりの差異が認め られている ${ }^{8) 9}$. 従来より PRWP と前壁中隔心筋梗 塞との関連を強調する報告 ${ }^{10) ~ 14)}$ が多いが, 最近 Hiyoshiら ${ }^{15)}$ は， $V_{1} か ら V_{4}$ 誘導でQS patternを示 した症例で，剖検上心筋梗塞を確認し得たのは約 $20 \%$ に過ぎなかつたと報告している.

今日までに標準12誘導心電図やベクトル心電図 を用いて，心筋梗塞によるPRWPと他の原因疾患 に基づくPRWPとの鑑別診断が試みられてきた。 Zemaら ${ }^{3)}$ は，ベクトル心電図で得られた鑑別因子 を標準12誘導心電図に利用して，前壁中隔心筋梗 塞, 左室肥大, Cタイプ右室肥大, 正常を枝分か れ論理を用いて鑑別する診断基準を作成した。そ
の診断基準は次のとおりである.(1) 前壁中隔心筋 梗塞： $\mathrm{V}_{3}$ 誘導の $\mathrm{R}$ 波高值が $0.15 \mathrm{mV}$ 以下である か, I 誘導の $\mathrm{R}$ 波高値が0.4mV以下. (2) 左室肥 大： 既存の心電図上の左室肥大基準に該当する ๖の. (3) 右室肥大： I 誘導の $\mathrm{r}$ 波高值が0.4 $\mathrm{mV}$ 以下で, かつ I 誘導の $\mathrm{S}$ 波高値が $0.1 \mathrm{mV}$ 以上. (4) 正常： 以上のいずれにも相当しない場合.

Zemaらは，これらの診断基準を用いることに より，前壁中隔心筋梗塞ではsensitivity $90 \%$, specificity $72 \%$, 右室肥大ではsensitivity $86 \%$, specificity $94 \%$, 左室肥大ではsensitivity $75 \%$, specificity $90 \%$ の好成績を報告している.

しかし,この診断基準を自験例で試みたところ, sensitivity 上specificityはそれぞれ，前壁中隔心筋 梗塞では $82.1 \% ， 61.6 \%$, 肺疾患では $56.4 \%$,

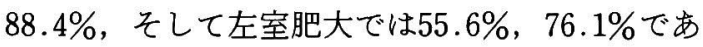




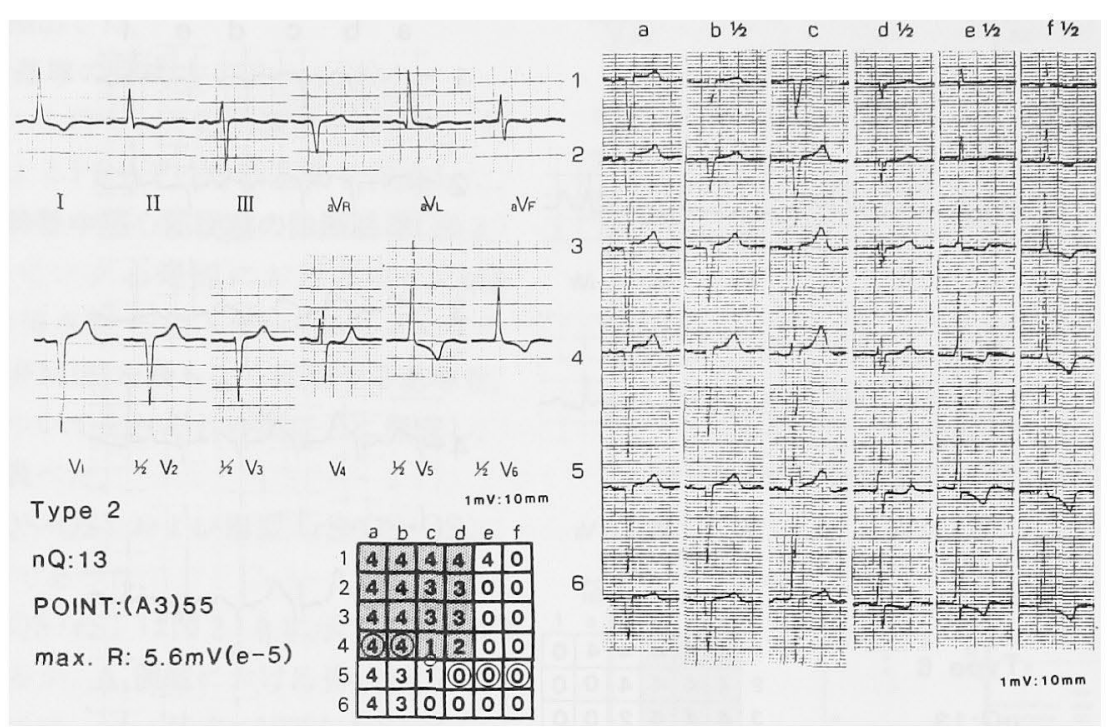

図 4, 症例 2 左室肥大例.

大動脈弁狭窄症の 54 才の女珄. ${ }^{201} \mathrm{~T} l$ 心筋シンチグラムにおいて欠損像を認めない. 心エュー図で; 心室中隔の壁厚は $12 \mathrm{~mm}$ であつた. 標準 12 誘導心電図では, $V_{5}$ 誘導で $R$ 波高値 $5.4 \mathrm{mV}$ の高電位差およびストレインパターン様の虚血性変化が認められた左 室肥大の所見である. 加えて $V_{1} V_{2}$ 誘導がQS patternで，II型のPRWPを示しており， 心筋梗塞の合併が強く疑われる. 前胸壁マッピング心電図ではnQが13, $\mathrm{A}_{3}$ 領域の得点 が55点と，いずれも前壁中隔心笳梗塞の基準を満足しない（e-5)誘導の R波が最大棘 波で5.6mV, T波の陰転が $\mathrm{f}$ 誘導に認められ，左室肥大の基準を満足し，前壁中隔心筋 梗塞を伴わない左室肥大と診断される.

り，Zemaらの成績と比べてかなり劣つていた。

このようにZemaらの診断基準に再現性のない ことは，標準12誘導心電図を用いてのPRWPの鑑 別診断には，自ずと限界があることを示唆してい ると思われる。

そこで本研究では，36誘導よりなる前胸壁マッ ピング心電図を用いて, PRWPを呈する前壁中隔 心管梗塞, 左室肥大, 正常人を枝分かれ論理を用 いて鑑別する診断基準の作成を試みた。

本研究での対象症例中には, I 型 $(\mathrm{QS} \cdot \mathrm{QS} \cdot \mathrm{QS})$ やIII型 $(\mathrm{rS} \cdot \mathrm{QS} ・ \mathrm{QS}) \cdot の よ う に$ 標準 12 誘導心電図 のみで鑑別可能な症例が含まれていることを考慮 し，基準を型別に作成することによつて，鑑別診 断の困難な症例の診断率を高めることを目的とし た。この I・III型を除外した本研究の対象症例は, Zemaの対象症例とほぼ同質の症例を選択したこ とになり，両者の診断基準は，相互に比較し得る
ものと考えられる.

本研究において，マッピング心電図で異常 $\mathrm{Q}$ 波 を示す誘導の数は, 全ての型で心筋梗塞群に多く 認められた。また，VI型のよ5に標準12誘導心電 図ではQS patternを認めない症例でも，胸部の 6 誘導より上方の体表面には異常 $\mathrm{Q}$ 波がかくされて いることが判明した。

しかし，非梗塞群においても，右上方の誘導に 向からに従い, R波は減衰し, 数こそ少ないがQS patternを示す誘導が存在した。このことは Grant $^{16)}$ の言う anterior null zoneの考党によつて 説明されると思われる。

Zemaら ${ }^{17)}$ は, 正常例についての検討を行ない, null zoneは胸部誘導より上方に向かつて存在し, 上方に行くほど r 波が減高することを証明した。 このために，標準12誘導心電図の胸部誘導をより 上方につけまちがえることがfalse positive 


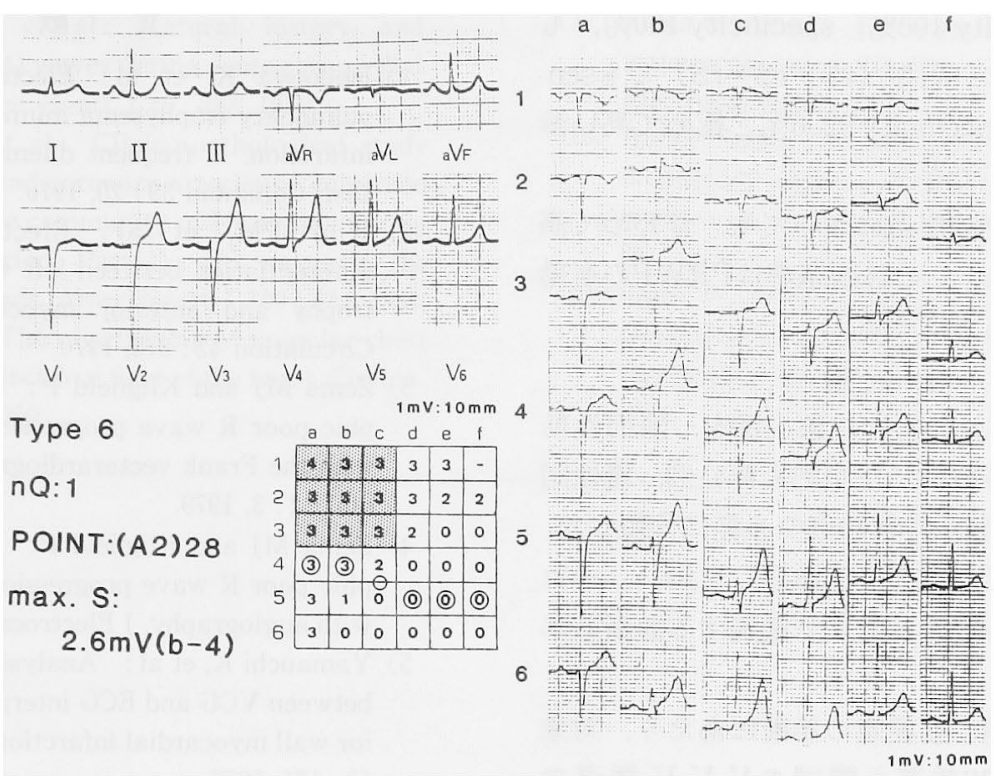

図 5. 症例 3 正常例.

慢性副鼻腔炎で当院外来を受診した38才の男性. 理学的所見および胸部X線像によ り心循環系に異常を認めない。標準12誘導心電図ではVI型のPRWPを示した。前胸壁 マッピング心電図においてnQは(a-1)誘導の $1 ， A_{2}$ 領域の得点は28点で, いずれる前 壁中隔心筋梗塞の診断基準を満足しない，最大棘波高値は (b-4) 誘導の $\mathrm{S}$ 波で $2.6 \mathrm{mV}$ で， $\mathrm{T}$ 波の陰転は $\mathrm{a}$ 誘導に認められ，左室肥大の基準を満足しない.さらに(e-6) 誘 導に S 波は認められず，肺疾患の基準も満足しない。したがつて正常型のPRWPと診 断される.

PRWPを増加させ, 下方につけまちが党ることが false negative PRWPを増加させると説明した.

このことは, 非梗塞群における異常 $\mathrm{Q}$ 波発生の 機序を説明し得ると思われる. 左室肥大では左後 上方へ ${ }^{18)}, \mathrm{C}$ タイプの右室肥大では右後上方へと cardiac centerが移動するため ${ }^{19}$ ，右前胸部にnull zoneが出現し， $V_{1} V_{2} V_{3}$ 誘導に拈いて異常 $Q$ 波が 認められるようになる。，そこで本研究では，非梗 塞群に打ける $\mathrm{r}$ 波の減衰度之心筋梗塞群に打ける $\mathrm{r}$ 波の減衰度を定量的に比較する目的で， $\mathrm{r}$ 波の 减衰度に応じて得点を付与し, 両者間の減衰度の 差を比較した。 その結果, 梗塞群においては $\mathrm{A}_{1}$ 領 域ですでに非梗塞群よりも強い $\mathrm{r}$ 波の減衰もしく は消失が認められ, $\mathrm{A}_{2}$ から $\mathrm{A}_{3}$ 領域へと領域が広が るに従つて直線的に得点が増加した。一方, 非梗 塞群では $\mathrm{A}_{1}$ 領域で減衰度が最も低く, 左下方の領 域に広がるに従つて得点の伸びは低下し, 梗塞群
との差が広がつた。このことは，非梗塞群に损け るR波の減高がnull theoryに一致したR波の減衰 を表すものであり，梗塞群の病的な $\mathrm{r}$ 波の減衰と は性格を異にするものであるのか子知れない。こ の梗塞群の病的な減衰とは, null theoryによる r 波の減衰に心起電力の減衰が加わつたものと考光 られる。

標準12誘導心電図の胸部誘導は，体表面に括け る電位の分布を線でしかとらえられないために， anterior null zoneの影響を受けやすいのに対し， 前胸壁マッピング心電図は，面としてとらえるこ とによつて, false negative拉よびfalse positiveを 减少させより高い診断率が得られるものと期待 できる。

異常 $\mathrm{Q}$ 波の数と $\mathrm{R}$ 波の減衰度（得点法）から得 られた心筋梗塞の診断基準によつて, II 型（QS・ $\mathrm{QS} \cdot \mathrm{rS}), \mathrm{IV}$ 型 $(\mathrm{QS} \cdot \mathrm{rS} \cdot \mathrm{rS}), \mathrm{V}$ 型 $(\mathrm{rS} \cdot \mathrm{rS} \cdot$ 
QS)ではsensitivity 100\%, specificity 100\%， つとも判定の難しいVI型（rS・rS・rS）でもsensitivity $87.5 \%$, specificity $92.6 \%$ と極めて高い診 断率を得ることができた。

左室肥大および肺疾患においても，きわめて高 率の診断がなされ，この診断基準はPRWPの有効 な鑑別基準であると考学る。

\section{結 論}

PRWPを示した160例の対象症例を，陳旧性前 壁中隔心筀梗塞群61例，左室肥大群41例，慢性閉 塞性肺疾患群18例, 正常群40例の 4 群に分類した. 前胸壁マッピング心電図（36誘導）を用い，それ ぞれの疾患群を枝分かれ方式で鑑別する診断基準 を作成した。

陳旧性前壁中隔心筋梗塞の診断にあたり，対象 症例全例を標準 12 誘導心電図の $V_{1} V_{2} V_{3}$ 誘導の QRS波形によって，以下の 6 型に分類した。Ｉ型 $(\mathrm{QS} \cdot \mathrm{QS} \cdot \mathrm{QS})$; II 型 $(\mathrm{QS} \cdot \mathrm{QS} \cdot \mathrm{rS})$; III型 $(\mathrm{rS} \cdot$ $\mathrm{QS} \cdot \mathrm{QS}) ; \mathrm{IV}$ 型 $(\mathrm{QS} \cdot \mathrm{rS} \cdot \mathrm{rS}) ; \mathrm{V}$ 型 $(\mathrm{rS} \cdot \mathrm{rS} \cdot$ $\mathrm{QS})$ ； VI型（rS・rS・rS）。I型およびU型は全例 心筋梗塞例であつたため，II 型・IV型，V型・VI 型について，前壁中隔心筋梗塞群と非梗塞群（左 室肥大群・肺疾患群・正常群）の比較検討を行な つた.この 2 群間の診断には36誘導中のQ波の数, および $\mathrm{r}$ 波高值に基づいて作成された得点洗が用 いられた。各型ごとに決められた診断基準により， II, IV $・ \mathrm{~V}$ 型はsensitivity $100 \%$, specificity $100 \%$ で前壁中隔心筋梗塞が診断された，最も診断率の 劣るVI型においても sensitivity $87.5 \%$ ， specificity $92.6 \%$ と極めて高い診断率が得られ た.

さらに左室肥大群と肺疾患招よび正常群, 肺疾 患群之正常群の比較検討によつて，左室肥大㧊よ び肺疾患を鑑別する診断基準を作成した。これら の結果を用い，PRWPの診断基準を作成した。

前胸壁マッピング心電図によつて，前胸壁の広 範な心電図変化を面としてとらえたことが，線の 変化としての標準 12 誘導心電図診断よりも診断率 を向上させる結果になつた。

\section{文献}

1) Ishikawa $K$, et al: Electrocardiograms in pulmonary emphysema mimicking myocardial infarction. A frequent dilemma. Med. Annals Dist. Columbia 39: 20, 1970.

2) Kini PM, et al: Electrocardiographic differentiation between left ventricular hypertrophy and anterior myocardial infarction. Circulation $42: 875,1970$.

3) Zema MJ and Kligfield P: Electrocardiographic poor $\mathrm{R}$ wave progression. I : Correlation with the Frank vectorardiogram. J Electrocardiol $12: 3,1979$

4) Zema MJ and Kligfield P: Electrocardiogra. phic poor $\mathrm{R}$ wave progression. II : Correlation with angiography. J Electrocardiol $12: 11,1979$.

5) Yamauchi $K$, et al: Analysis of discrepancies between VCG and ECG interpretation of anterior wall myocardial infarction. J Electrocardiol $10: 171,1977$.

6) Young $E$, et al: Vectrocardiographic diagnosis and electrocardiographic correlation in left ventricular asynergy due to coronary artery disease. I. Severe asynergy of the anterior and apical segments. Circulation 51:467, 1975.

7) Gunnar RM, et al : Correlation of vectorcardiographic criteria for myocardial infarction with autopsy findings. Circulation 35 : 158, 1967.

8) Surawicz B, et al: QS-and QR-pattern in leads V3 and V4 in absence of myocardial infarction: Electrocardiographic and vectorcardiographic study. Circulation $12: 391,1955$.

9) Jedlicka J: The differential diagnostic significance of the Qr and QS pattern in lead V1. Cardiologia 52: 170, 1968.

10) Horan LG, et al: Significance of the diagnostic $Q$ wave of myocardial infarction. Circula tion $43: 428,1971$.

11) McConahay DR, et al: Comparative quantitative analysis of the electrocardiogram and vectorcardiogram. Correlations with the coronary arteriogram. Circulation 42: 245, 1970.

12) Levine HD, et al: Electrocardiogram and vectorcardiogram in myocardial infarction. Circulation 45: 457, 1972.

13) Starr JW, et al: Vectorcardiographic criteria for the diagnosis of anterior myocardial infarction. Circulation 53:229, 1976. 
14) Selwyn AP, et al: Natural history and evaluation of $Q$ waves during acute myocardial infarction. Brit Heart J 40:383, 1978.

15) Hiyoshi $Y$, et al: Clinico-pathological study of the heart and coronary arteries of autopsied cases from the community of Hisayama during a 10-year period. Part IV. QS waves in the precordial leads. Amer Heart J 100: 424, 1980.

16) Grant RP: The relationship of unipolar chest leads to the electrical field of the heart. Circulation I: $878,1950$.
17) Zema MJ, et al : Electrocardiographic poor $\mathrm{R}$ wave progression. III. The Normal Variant. J Electrocardial 13: 135, 1980.

18) Abbott-Smith CW and Chou TC: Vectorcardiographic criteria for the diagnosis of left ventricular hypertrophy. Amper Heart J 79 : $361,1970$.

19) Chou $\mathrm{TC}$, et al: Simple quantitative vectorcardiograhpic criteria for the diagnosis of right ventricular hypertrophy. Circulation $48: 1262$, 1973. 